Proc. Indian Acad. Sci. (Earth Planet. Sci.), Vol. 99, No. 1, March 1990, pp. 141-152.

(C) Printed in India.

\title{
Redox state of the upper mantle
}

\author{
ARNOLD A KADIK \\ Vernadsky Institute of Geochemistry and Analytical Chemistry, USSR Academy of Sciences, \\ Moscow 117975, USSR
}

\begin{abstract}
The oxygen fugacity condition of equilibration has been carefully determined from a spinel lherzolite from Mongolia, olivine xenocrysts from chrome pyrope-bearing peridotite nodules from kimberlites of Yakutia, and basaltic samples from ocean floor, iron arcs and the continental areas. These indicate that the spinel lherzolites occurring within alkali basalts from Mongolia, equilibrated under an $f_{\mathrm{O}_{2}}$ condition similar to that of WM buffer. The diamond and chrome pyrope-bearing peridotites from the kimberlite pipes equilibrated between IW and WM buffers. Some of the ilmenite-bearing peridotite crystallized under $f_{\mathrm{O}_{2}}$ conditions similar to that between WM and QFM buffers and chondrites equilibrated below the QFI buffer.

It is concluded that during geochemical processes in the upper mantle the $f_{\mathrm{O}_{2}}$ conditions vary broadly, and are similar to that between FMQ and IW buffers.

There is a dramatic change in the composition of the kimberlitic fluid, which is $\mathrm{CH}_{\mathbf{4}}$-bearing at an early stage, but is in equilibrium with $\mathrm{H}_{2} \mathrm{O}$ and $\mathrm{CO}_{2}$ at a later stage. This is related to mass transfer of fluids from the lower part of the mantle with a low oxidation state to the upper part having a higher $f_{\mathrm{O}_{2}}$ condition.
\end{abstract}

Keywords. Redox state; upper mantle; oxygen fugacity; spinel lherzolite; olivine xenocryst; peridotites.

\section{Introduction}

The redox state of the fluid regimes of the earth's lithosphere and asthenosphere is of great importance to petrologists (Haggerty and Topkins 1985; Green et al 1986, Haggerty 1986, Kadik 1988). The redox state of the material at depth controls the composition of the volatile components, which in turn play a major role in the ultimate differentiation and fractionation of the melt. The generation of specific types of basaltic magmas in the mantle below a certain specific region of the ocean, formation of alkali basaltoid liquids in the rift zones and kimberlitic magmas below the cratons, lead us to the conclusion that there are specific physico-chemical regimes within the mantle, which are responsible for the production of specific types of melts. The issue now, is to evaluate the redox states of such different fluid regimes of the earth.

The discussion is focussed on the following problems: (i) Whether the lithosphere and asthenosphere are homogeneous with respect to their redox states. (ii) What were the values of oxygen fugacities during the evolution of the mantle? Whether the $f_{\mathrm{O}_{2}}$ condition was so low as to form iron and nickel-bearing phases in the early stages of mantle formation? (iii) Does the redox state of the mantle below the ocean, differ from that of the mantle below the continents? (iv) What are the factors responsible for changes in the redox regime of the lithosphere and the asthenosphere? 


\section{Results and discussion}

One of the aspects under discussion is the nature of the fluids in the lower mantle which are introduced into the continental lithosphere and asthenosphere in the areas of formation of kimberlitic liquids. There are two contrasting views: (i) Such fluids were low in their oxygen fugacity and rich in $\mathrm{CH}_{4}$ and became progressively oxidized during their ascent to the upper mantle (Sobolev 1977; Haggerty and Topkins 1985; Green et al 1986). (ii) The fluids were under higher oxidation state but underwent reduction as they came in contact with the upper mantle material (Arculus et al 1984).

The resolution of this problem is of crucial importance, for in the first case, oxidation of reduced fluids should result in melting.

There are several ways of determining oxygen fugacity related to mineral reactions at depth, which employ thermodynamic and experimental techniques (table 1). None of them is free from drawbacks (Ulmer et al 1976; Arculus et al 1984; O'Neil and Wall 1987; Kadik et al 1988; Mattioli et al 1990). The present study assesses the role of oxygen during reactions at depths by directly measuring $f_{\mathrm{O}_{2}}$ with electrochemical cells (for such studies refer Kadik et al 1988; Kadik et al 1989; Kadik and Zharkova 1990).

The spinel lherzolite nodules from alkali basalts of Mongolia are rather close in composition to the primitive upper mantle. The crystals are of pure gem quality and free from fluid or other inclusions (Press et al 1986).

The investigation also includes a study of olivines from diamond and chrome pyrope-bearing peridotite nodules within kimberlites from Yakutia. These nodules are supposed to be largely disintegrated representatives of the ancient lithosphere and asthenosphere (Pokhilenko and Sobolev 1986). Also studies on some basaltic flows from the ocean floor, island arcs and continents (Kadik and Zharkova 1990) are included.

The data obtained in the experimental runs are given in figures 1,2 and 3. From the figures, the $f_{\mathrm{O}_{2}}$ condition of formation of the spinel lherzolites is estimated to be close to the equilibrium condition maintained by the wustite-magnetite buffer, although some of the samples reveal a slightly lower level of oxygen fugacity, close to the condition of the equilibrium of iron and wustite.

This experimental data do not agree with the rather low values of oxygen fugacity of Arculus et al (1984) who inferred that the samples of spinel lherzolites equilibrated under an $f_{\mathrm{O}_{2}}$ condition, which is below the IW buffer. Our observation thus contradicts their conclusion on the existence of two groups of rocks in the upper mantle; those formed under reduced condition and the other equilibrated under higher $f_{\mathrm{O}_{2}}$ conditions.

Table 1. Various methods related to the determination of $f_{\mathrm{O}_{2}}$ for reactions at depth.

1. Thermodynamic calculations of $f_{\mathrm{O}_{2}}$ for different mineral assemblages (olivine-orthopyroxene-spinel, olivine-orthopyroxene-ilmenite, garnet-orthopyroxene-olivine and ilmenite-spinel).

2. $\mathrm{Fe}^{2+} / \mathrm{Fe}^{3+}$ ratio in volcanic glasses as a function of $f_{\mathrm{O}_{2}}$.

3. Presence of free graphite in fluid inclusions reflecting a particular $f_{\mathrm{O}_{2}}$ value.

4. Use of electrochemical cells to measure $f_{\mathrm{O}_{2}}$ condition of equilibration for mineralogical reactions at depth. 


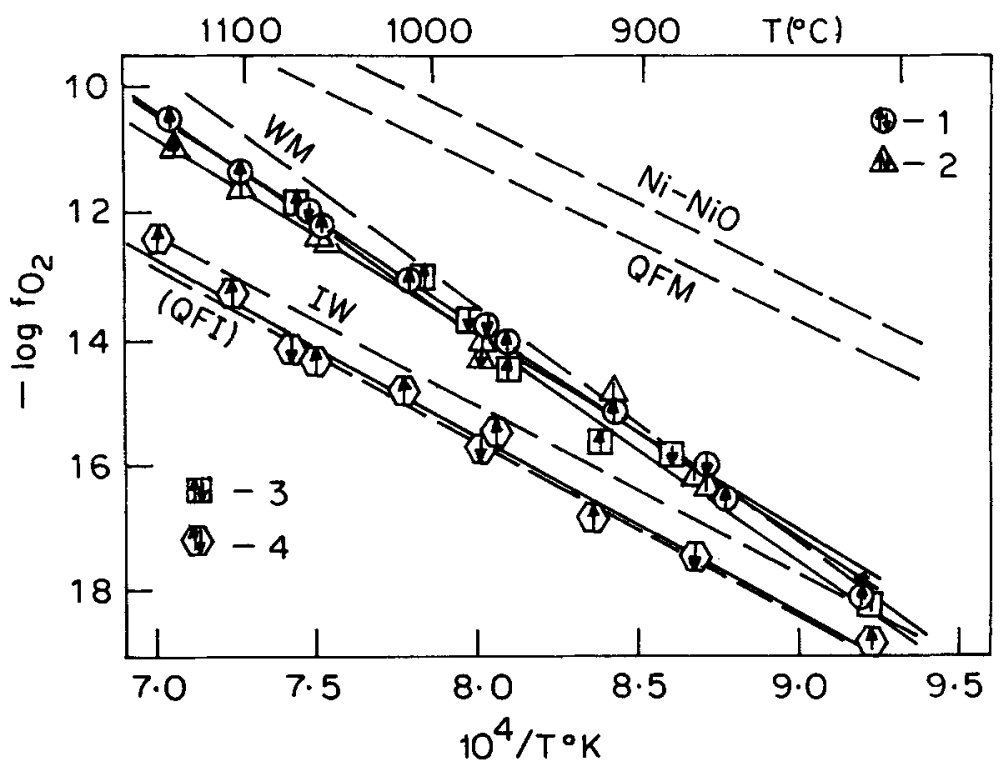

Figure 1. Examples of intrinsic oxygen fugacity measurements of spinel lherzolite nodules (alkali basalts, Mongolia) and diamond and pyrope-bearing peridotite (kimberlite, Yakutia) 1: orthopyroxene, 2: olivine from spinel lherzolite, 3: olivine from sheared diamond-bearing peridotite, 4: olivine from diamond-bearing chrome peridotite. Quartz-fayalite-magnetite (QFM) buffer, wüstite-magnetite (WM) buffer, wüstate-iron (WI) buffer, quartz-fayalite-iron (QFI) buffer plotted at 1 bar.

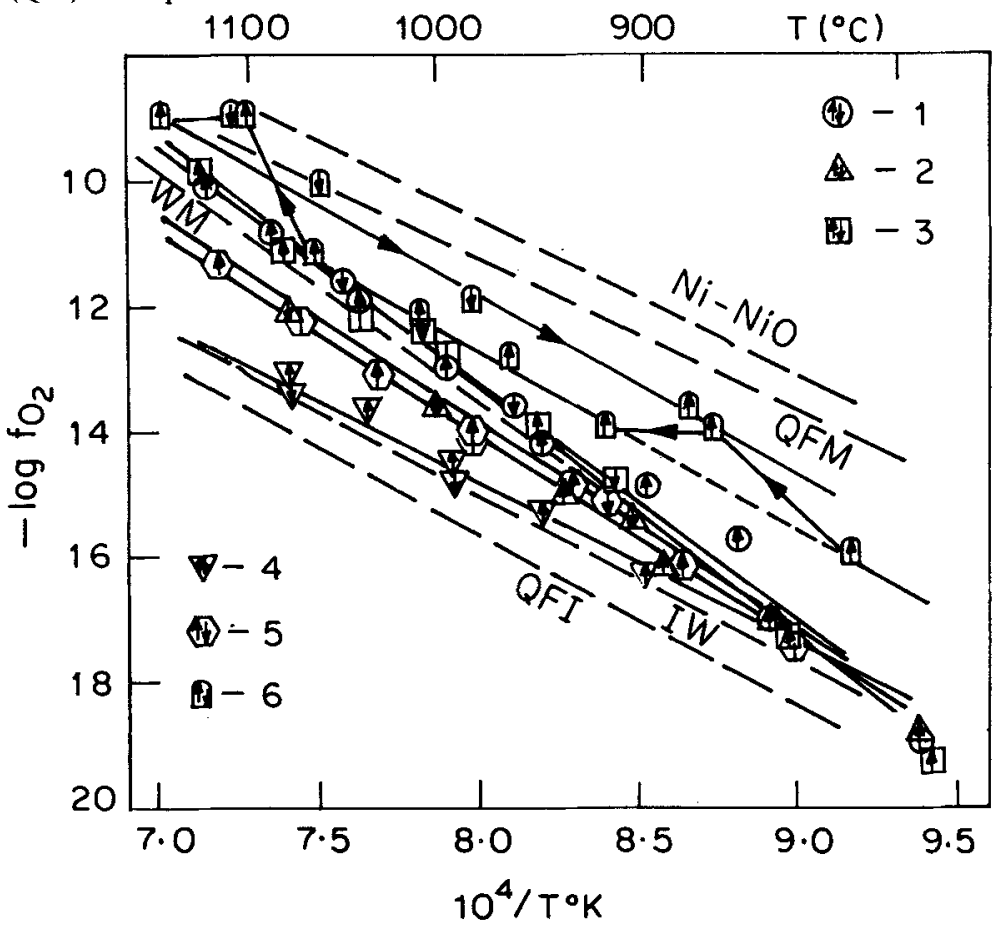

Figure 2. Examples of intrinsic fugacity measurements of minerals and glasses from basalts and kimberlites. 1, 2, 3: olivine from alkali basalts of rift zone (Baikal lake, Iceland Africa); 4, 5: olivine from kimberlites (Yakutia); 6: glasses of alkali basalts (Mongolia). 


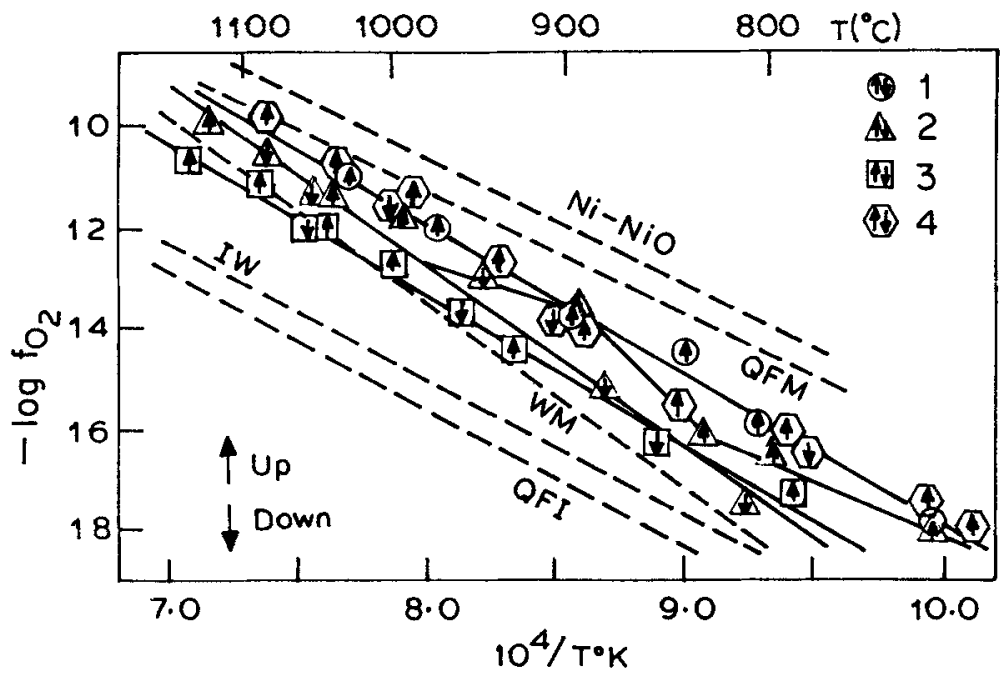

Figure 3a. Examples of intrinsic oxygen fugacity measurements of minerals and glasses from basalts of island arcs and ocean basin: 1: Central Atlantic, 2: Indian Ocean, 3: Northern Atlantic, 4: Hawaii.

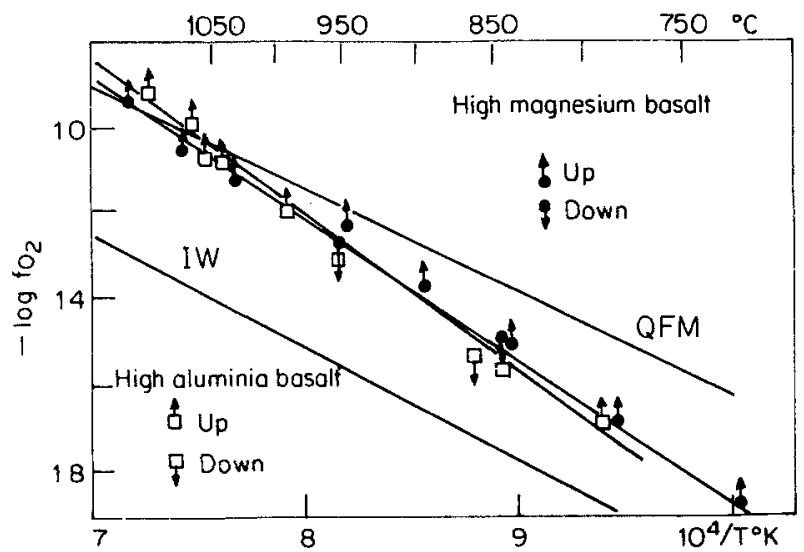

Figure 3b. Bulk rock samples of basalts from Kamchatka.

The same spinel lherzolites which were used by Mattioli et al (1990, also see table 2) were studied and the observations agree well with their findings. The values of oxygen fugacity as estimated for spinel lherzolites, strengthen the possibility of the existence of a graphite phase in the $\mathrm{P}$-T regime, where these ultramafic rocks originally occurred. These are also the regions where basaltic magmas are generated in the mantle. This inference is of considerable importance on the composition of the fluid phase, which varies as a function pressure and $f_{\mathrm{O}_{2}}$ (figure 4).

This conclusion is confirmed by the presence of rare and extremely fine-grained crystals of graphite in minerals in the spinel lherzolite nodules included within alkali-basaltiod rocks from Mongolia. The presence of graphite was confirmed by the Raman spectroscopic techniques.

However, the possible dissolution of carbon in crystals and melts would inhibit its 
Table 2. Comparison of experimental data of intrinsic oxygen fugacity for minerals of a spinel lherzolite included within alkaline basalt as xenoliths of Shavaryn-Tsaram volcano (Northern Mongolia) (Kadik et al 1988) with thermodynamic data carried out by Mattioli et al (1990) for the same samples.

\begin{tabular}{llccc}
\hline Sample & Mineral & $t\left({ }^{\circ} \mathrm{C}\right)$ & $\begin{array}{c}-\log f_{\mathrm{O}_{2}} \\
\text { (determined) }\end{array}$ & $\begin{array}{c}-\log f_{\mathrm{O}_{2}} \\
\text { (calculated) }\end{array}$ \\
\hline \multirow{4}{*}{ MOZ } & OI & & 13.22 & \\
& Opx & 1011 & 13.04 & 13.20 \\
& Cpx & & 13.42 & \\
& Spl & & 13.16 & \\
MHP 79/1 & Ol & & 13.92 & \\
& Opx & 1004 & 13.73 & 13.11 \\
& Cpx & & 13.52 & \\
MHP 79/4 & OI & & 14.54 & 15.71 \\
& Opx & 956 & 14.20 & \\
\hline
\end{tabular}

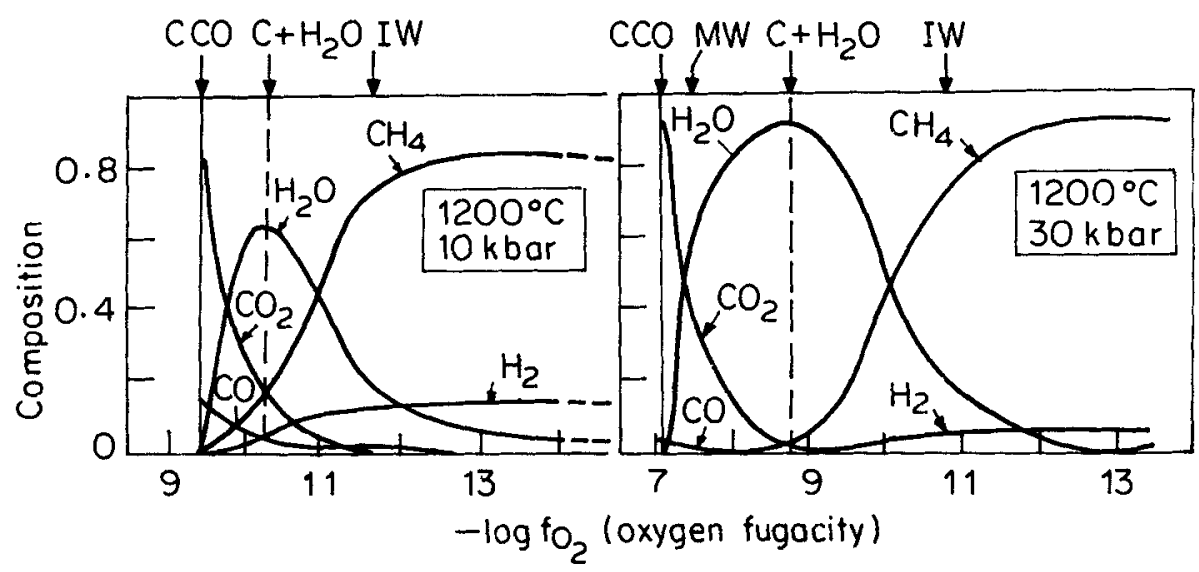

Figure 4. Effects of $f_{\mathrm{O}_{2}}$ on the composition of fluid phase in equilibrium with graphite in the $\mathrm{C}-\mathrm{O}-\mathrm{H}$ system at $1200^{\circ} \mathrm{C}$ and pressure at 10 and $30 \mathrm{~kb}$.

appearance in rocks as a separate phase. The experiments related to the interaction of graphite in olivine crystals and basaltic melts under 15 to $50 \mathrm{~kb}$ at temperatures between 1400 and $1800^{\circ} \mathrm{C}$ attest to the fact that the amount of carbon dissolved in a silicate melt and crystals may vary up to 0.01-0.10w\% (Shilobreeva et al 1989, Shilobreeva and Kadik 1990).

The olivines of mantle origin are saturated with respect to its graphite content (table 3), and it appears that the olivine-bearing mantle rocks were in equilibrium with graphite. The diamond and chrome pyrope-bearing peridotites from the kimberlite pipe of Udachnaya (Yakutia) reveal widely varying $f_{\mathrm{O}_{2}}$ conditions (between IW and WM buffers).

As there is progressive disintegration of the diamond-bearing peridotite xenoliths, it is considered that with the ascent of the kimberlitic fluid, the $f_{\mathrm{O}_{2}}$ condition of 
Table 3. The carbon content in natural olivines determined by the ${ }^{12} C(d, n){ }^{13} \mathrm{~N}$ method (1) and the method involving ${ }^{12} C(d, n)^{13} \mathrm{~N}$ nuclear reaction plus surface contamination by means of ${ }^{12} C(d, p){ }^{13} C$ reaction (2). (Shilobreeva et al 1987)

\begin{tabular}{|c|c|c|c|}
\hline Rock Type & $\%$ Fo & $\begin{array}{c}\text { Carbon content, } \\
\text { Wt } \%\end{array}$ & Method \\
\hline Nodule from spinel lherzolite (Baikal rift) & 89.6 & $0.08+0.01$ & 1 \\
\hline Megacryst from alkali basalt (Baikal rift) & $91 \cdot 4$ & $0.04+0.02$ & 1 \\
\hline Megacryst from picrite of pillow lava (Iceland) & $89 \cdot 4$ & $0.03+0.02$ & 1 \\
\hline Megacryst from tuff (Oldoinyo Lengai volcano, Africa) & $80 \cdot 5$ & $0.04+0.03$ & 1 \\
\hline Nodule from alkali basalt (Baikal rift) & 90.5 & $0.038+0.007$ & 2 \\
\hline Megacryst from alkali basalt (Shavaryn-Tsaram volcano, & $89 \cdot 9$ & $0.09+0.01$ & 1 \\
\hline Mongolia) & & $0.08+0.01$ & 2 \\
\hline Monocrystal from avachita (Kamchatka) & $89 \cdot 7$ & $0.08+0.03$ & 1 \\
\hline Nodule of alkali basalt San Carlos (Arizona, USA) & $91 \cdot 1$ & $0.017+0.008$ & 1 \\
\hline Nodule from spinel + amphibole lherzolite (Baikal) & & $0.0003+0.0001$ & 2 \\
\hline Nodule from garnet lherzolite & & $0.0012+0.0002$ & 2 \\
\hline Nodule from spinel therzolite (Mongolia) & & 0.0002 & 2 \\
\hline Nodule from spinel lherzolite (Mongolia) & & $0.0005+0.0001$ & 2 \\
\hline
\end{tabular}

equilibrium also increases (figure 5). The highest $f_{\mathrm{O}_{2}}$ values are characteristics of those xenoliths which show signs of cataclasis or which contain ilmanite. It may be concluded that the diamond-bearing peridotitic xenoliths from the upper mantle suffer a substantial change in the redox state.

Ideas about the $f_{\mathrm{O}_{2}}$ condition of equilibrium of diamond and chrome pyrope-bearing peridotites help to evaluate the composition of the fluid phase, which might have been in equilibrium with these rocks (figure 6). It is estimated that at a pressure of $50 \mathrm{~kb}$ and a temperature range of 1000 to $1300^{\circ} \mathrm{C}$ the fluid in equilibrium with diamond-bearing peridotites should have widely varying $\mathrm{H}_{2} \mathrm{O}$ and $\mathrm{CH}_{4}$. The lowest $f_{\mathrm{O}_{2}}$ values are associated with fluids which are rather high in $\mathrm{CH}_{4}$ (about $90-97 \mathrm{~mol} \%$ ). In the case of ultramafic rocks (diamond and chrome pyrope-bearing dunite and olivinite), the content of $\mathrm{CH}_{4}$ sharply decreases, while that of $\mathrm{H}_{2} \mathrm{O}$ increases. Cataclastic lherzolites, ilmenite and pyrope lherzolites were found to have equilibrated under $f_{\mathrm{O}_{2}}$ conditions where $\mathrm{H}_{2} \mathrm{O}$ and $\mathrm{CO}_{2}$ could coexist in equilibrium with the fluid.

The $f_{\mathrm{O}_{2}}$ condition of equilibrium of kimberlite sills is similar to that of cataclastic lherzolites (McMohan and Haggerty 1984; Haggerty 1986; Haggerty and Topkins 1985; Sobolev et al 1986).

The following is an attempt to generalize the experimental and thermodynamic data on the oxygen fugacity conditions involving mineral reactions at depth, which have been reported in numerous publications. Our observation regarding the redox state of lithosphere and the upper part of the atmosphere is illustrated in figure 7.

Figure 8 shows a similar generalization regarding the redox state of the region of formation of basic magmas in the mantle below the continents (stratified intrusive suites of Bushveld, Skaergaard, Stillwater, ete.), as well as the data on basalts of the oceanic floor. It follows from the diagram that the oxygen fugacity values of basaltic rocks correspond to the redox state of spinel lherzolites in the mantle below both the continents and the ocean. In general, magmatic melts show a gradual decrease in the oxygen fugacity values in the course of their ascent to the earth's surface. 


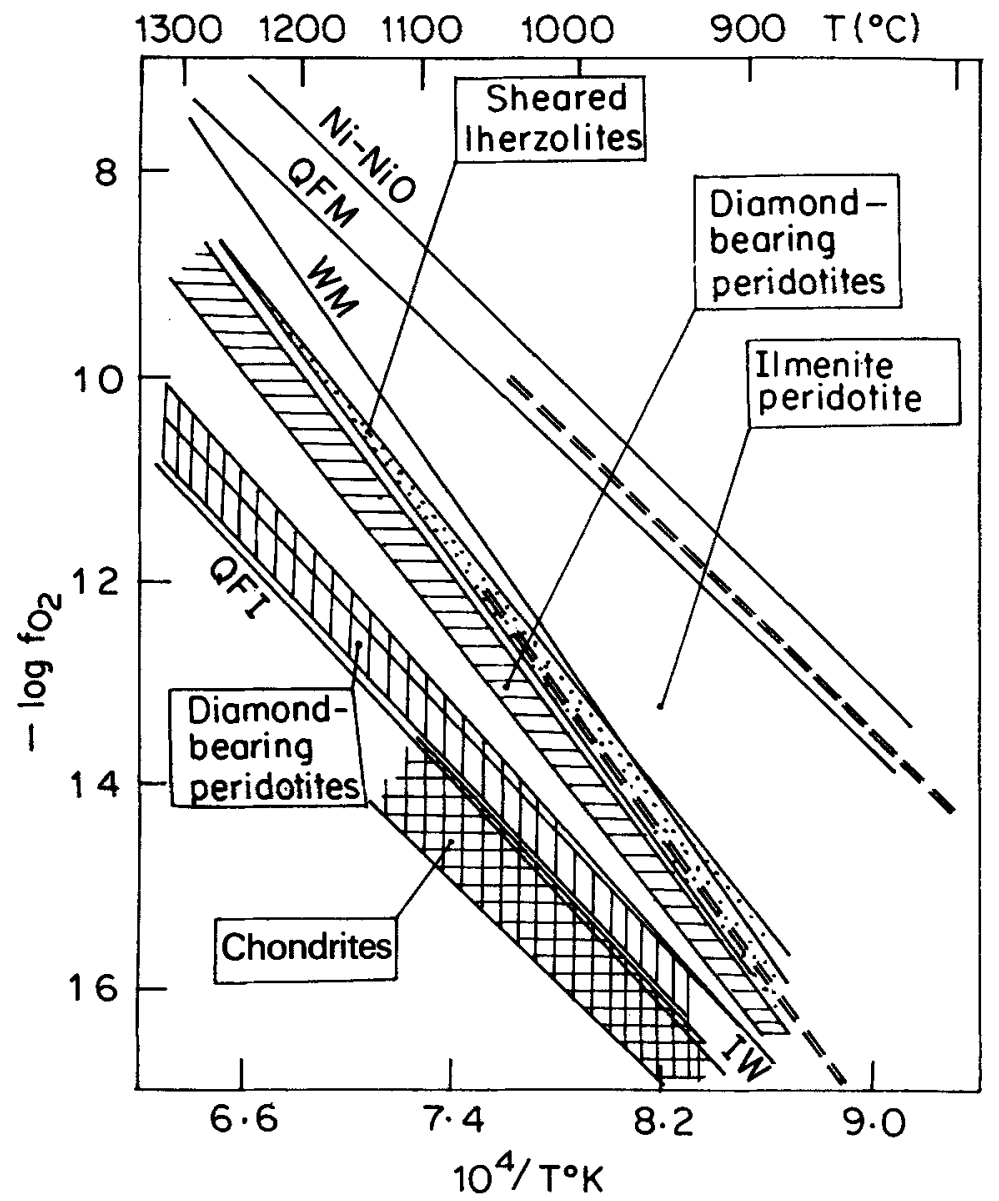

Figure 5. Summary of intrinsic oxygen fugacity measurements for diamond-bearing peridotite (kimberlite tubes, Yakutia).

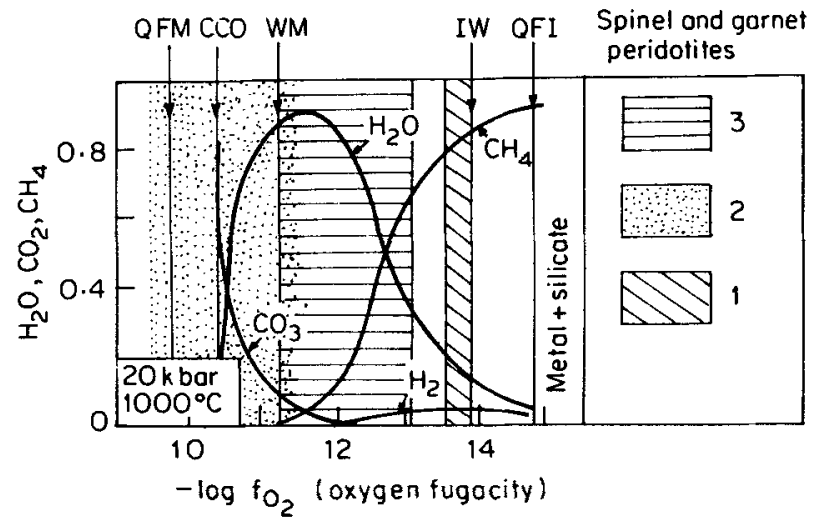

Figure 6. Composition of the fluid in equilibrium with diamond-bearing peridotite in the $\mathrm{C}-\mathrm{O}-\mathrm{H}$ system as a function of $f_{\mathrm{O}_{2}}$ at $50 \mathrm{~kb}$ and $1000^{\circ} \mathrm{C}$ (Kadik et al 1989). 1: diamondbearing chrome-pyrope herzburgite and lherzolite (low degree disintegration); 2: diamondbearing dunite and sheared lherzolites: .3; diamond-bearing ilmenite-pyrope lherzolite, kimberlite. 

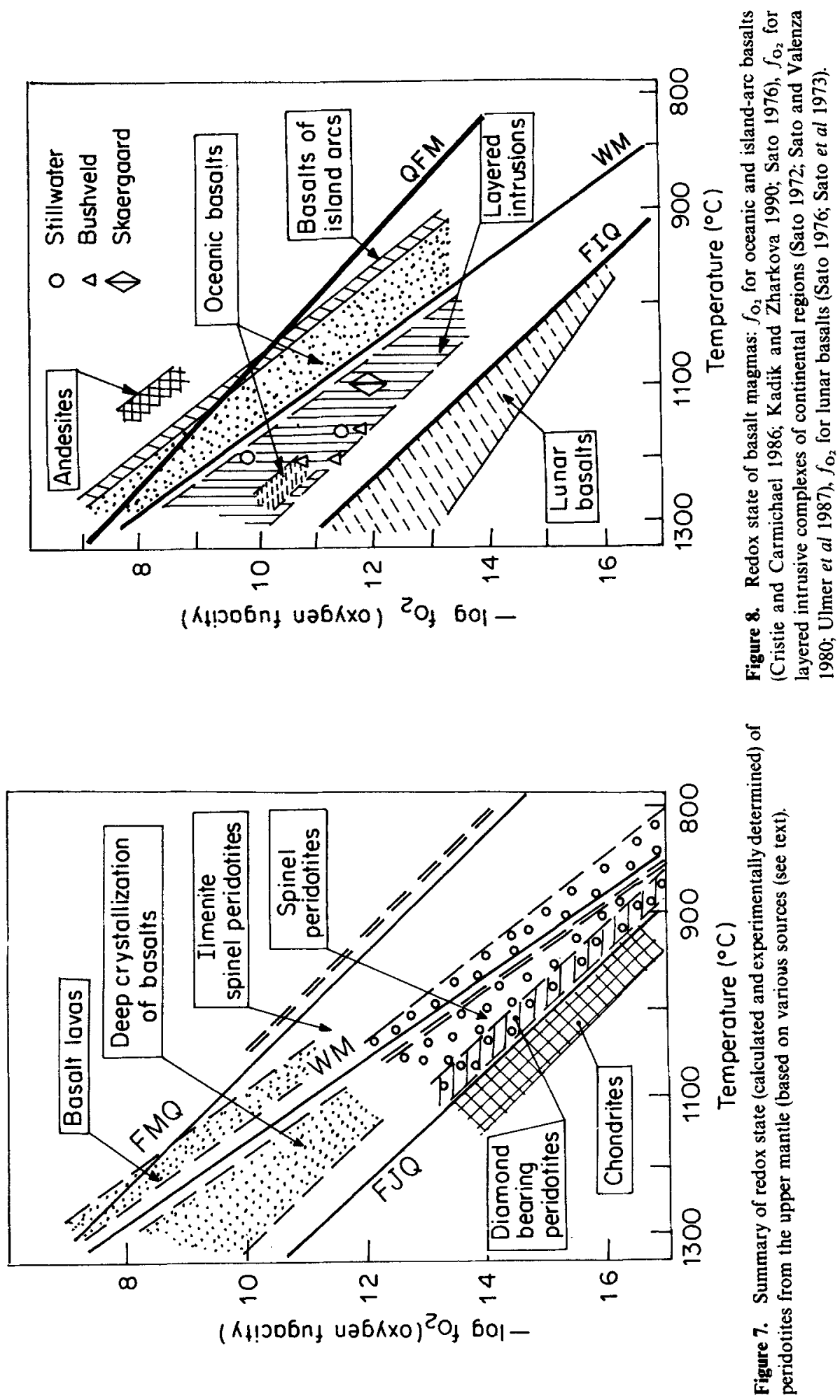
Our conclusion regarding the redox state of the upper mantle below the continental areas is as follows:

The $f_{\mathrm{O}_{2}}$ values during different geochemical processes in the upper mantle vary broadly in the $f_{\mathrm{O}_{2}}-\mathrm{T}$ space defined by the FMQ and IW buffers and the degree of variation is in four orders of magnitude. The upper mantle is largely heterogeneous as far as its redox state is considered. This is largely due to a number of chemical processes taking place within the mantle (e.g. melting, degassing, etc.). This conclusion is consistent with the ideas of many workers: Sobolev (1977); Arculus (1984); Haggerty (1986) and Green et al (1986), regarding the redox state of the lithospheric and asthenospheric layers of the upper mantle.

The $f_{\mathrm{O}_{2}}$ values determined for spinel peridotites differ considerably from those required for iron-silicate equilibrium. This means that the redox state of the upper part of the mantle has evolved considerably, compared to the early stage of mantle formation, when iron and nickel-bearing phases were in equilibrium.

The $f_{\mathrm{O}_{2}}$ values for diamond and chrome pyrope-bearing peridotites (classified as disintegrated rocks of ancient lithosphere) are rather low and correspond to those under which condition iron-silicate equilibrium takes place. This substantiates the view that the mantle is well reduced during the early stages of its evolution.

We may regard the increase in the oxygen potential as a basic tendency of the evolution undergone by the lithospheric and asthenospheric layers as far as their redox states are concerned. In some ways it is associated with the ascent of the mantle and the processes involving melting and degassing. This will be discussed further.

The areas of formation of kimberlite magmas in the mantle below the continents show dramatic changes in the redox state of the fluid regimes. From our experimental data we conclude that the melting process is preceeded by a considerable increase in the $f_{\mathrm{O}_{2}}$ condition of fluids which are in equilibrium with $\mathrm{H}_{2} \mathrm{O}$ and $\mathrm{CO}_{2}$ rather than $\mathrm{CH}_{4}$, the concentration of the latter being higher in its early stage of evolution.

The process of kimberlite magma formation appears to be associated with oxidation of the fluids at the upper part of the mantle, during which period, they became enriched in water and $\mathrm{CO}_{2}$. The temperature of peridotite melting during this stage shows a sharp decrease. This inference can be illustrated with the variation in the peridotite melting temperature as a function of the concentration of the fluid phase in equilibrium with graphite (figure 9).

Now let us discuss the factors which might bring about considerable changes in the redox state of the mantle particularly in the lithospheric-asthenospheric layers. This received worldwide interest (Eggler 1983; Arculus and Delano 1984; Haggerty and Topkins 1985; Kadik and Lukanin 1985, 1986; Green et al 1986; O'Neil and Wall 1987; Kadik 1988 and Mattioli et al 1990; Woermann and Rosenhauer 1985).

The process of melting and degassing of the mantle may be considered as the two most important factors. Many peculiarities in the redox state of the upper mantle are related to the physicochemical state of the early mantle.

If the mantle was subjected to a large-scale melting in a global scale, leading to the formation of large volumes of magma, differentiation of a magma and fractionation of the volatile components would lead to changes in its redox states. The presence of graphite could play a major role, if it is assumed that the composition of the mantle was similar to that of carbonaceous chondrites. The idea that the upper part of the earth's mantle may be similar to carbonaceous chondrite is believed to be true by many geo-scientists. 


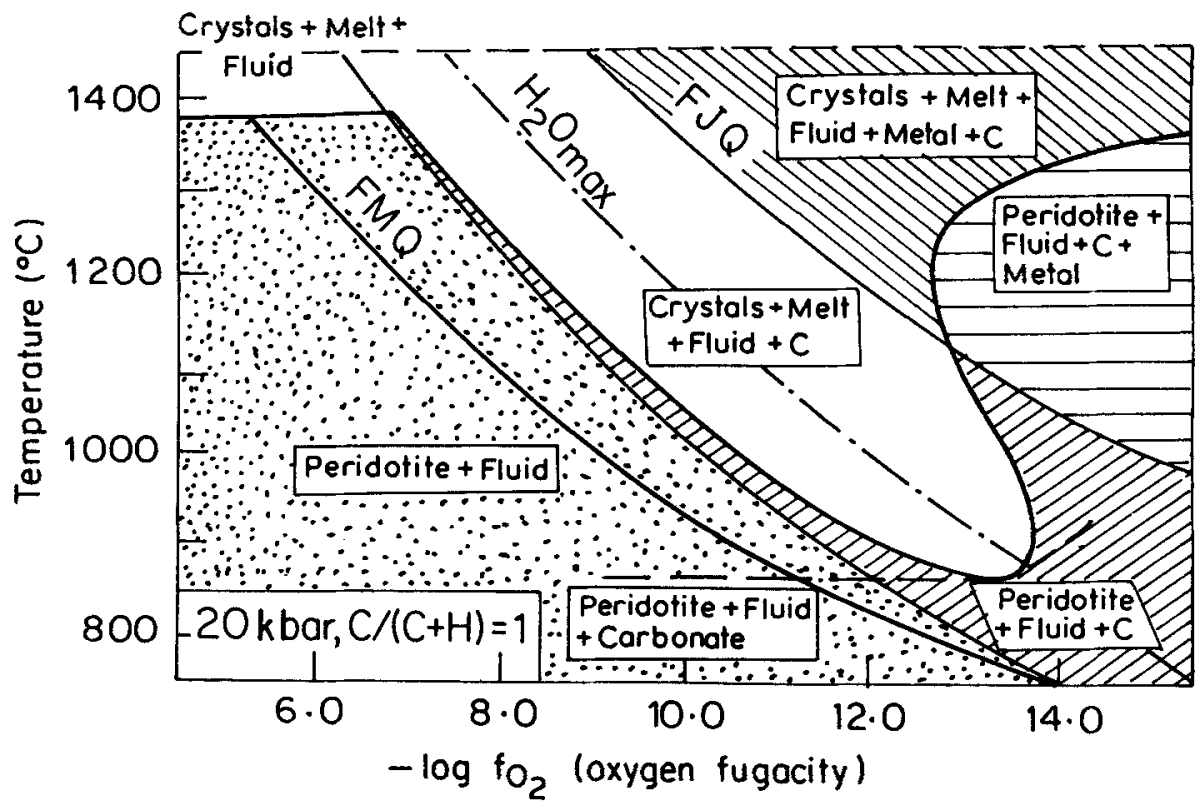

Figure 9. Effects of $f_{\mathrm{O}_{2}}$ on melting in the $\mathrm{C}-\mathrm{O}-\mathrm{H}$-peridotite system at $20 \mathrm{~kb}$ and $\mathrm{C} /(\mathrm{C}+\mathrm{H})=1$ (Lukanin and Kadik 1987).

Our views concur with that of Green et al (1986) and Haggerty (1986). We consider that the $\mathrm{CH}_{4}$-rich fluid ascending from the lower mantle interact with the more oxidized material of the lithosphere. The question is - what are the peculiarities associated with the fractionation of volatile components in the course of evolution of the layer undergoing global melting particularly if graphite was present in the parent material?

In the presence of a graphite phase, the content of such volatiles as $\mathrm{CO}_{2}, \mathrm{CO}, \mathrm{CH}_{4}$ and $\mathrm{H}_{2} \mathrm{O}$ should be largely controlled by the presence of a fluid phase (figure 10). Due to interaction between the graphite and the volatile components, species typical of reduced states such as $\mathrm{CO}, \mathrm{CH}_{4}$ and $\mathrm{H}_{2} \mathrm{O}$ should be predominant in the upper part of the melt layer, while the deeper part of the liquid layer should be associated with $\mathrm{H}_{2} \mathrm{O}$ and $\mathrm{CO}_{2}$. Because of contrasting compositional variation of the volatile composition, an intensive mass transfer would take place during the convective movement of the melt. The process should involve a generation of more oxidized melts and inflow of material from the deeper part of the liquid layer into the more reduced layers found near surface. This would inevitably result in the burning-out of graphite and oxidation of the melt in general.

Thus the condition of intensive convection and mass transfer favour the process of self-cleaning of the melt zone with respect to graphite. Simultaneously, the total oxygen potential of the system increases and the content of oxidized species of carbon becomes higher (see figure 10).

At the same time there are reasons to believe that in the top section of the upper mantle, there are layers with higher oxygen potential, compared to the deeper layers of the mantle. Subsequent process related to the melting of the upper mantle material should also result in increasing the $f_{\mathrm{O}_{2}}$ condition of the deep-seated layers.

If our contention is correct, the deeper part of the mantle which avoided melting 


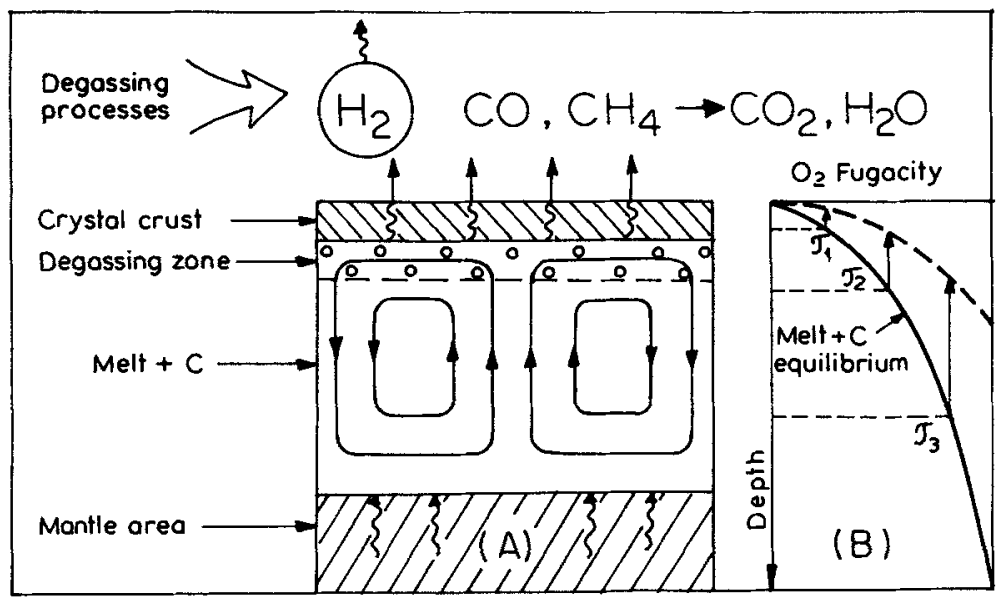

Figure 10. Outgassing in convecting magma layer (magma ocean) at the planetary surface (A) and supposed changes in $f_{\mathrm{O}_{2}}$ with height in presence of graphite, scheme showing increasing trends of $f_{\mathrm{O}_{2}}$ in magma layer during outgassing and graphite burning $\left(T_{1}, T_{2}, T_{3}\right)$ and dissipation of $\mathbf{H}_{2}(B)$.

at an earlier or later stage of earth's evolution probably has preserved more reduced states. These layers might be responsible for supplying fluids under highly reduced conditions to the lithospheric-asthenospheric layers of the upper mantle.

In the case of kimberlite magmas, there is a dramatic change in the composition of the fluid. It probably contains $\mathrm{CH}_{4}$ at an early stage, but are in equilibrium with $\mathrm{H}_{2} \mathrm{O}$ and $\mathrm{CO}_{2}$ at a later stage. Rather low values of $f_{\mathrm{O}_{2}}$ estimated for some samples of spinel lherzolites and continental and oceanic basalts suggest that even in these cases, magmatism was associated with mass transfer of fluids from the lower part of the mantle. However this conclusion warrants further discussion.

Thus we may conclude that the upper mantle is profiled with respect to its redox state, oxidized in the upper part (lithospheric and asthenospheric layers), but reduced in the deeper part (below the region of magma formation). This is in agreement in most aspects with the models proposed by Haggerty (1986). However, the main trend of evolution of the mantle involves oxidation in general.

\section{Acknowledgement}

We thank Dr Alok K Gupta for critically reading the manuscript. This paper is dedicated to the late Sir C V Raman, on the occasion of his birth centenary.

\section{References}

Arculus R J, Dawson J B and Mitchell R H 1984 Oxidation state of the upper mantle recorded by ilmenite megacrysts in kimberlite and type A and B spinel lherzolites; Contrib. Mineral. Petrol. 85 85-94

Arculus R J and Delano J W 1984 Intrinsic oxygen fugacity measurements: Techniques and results for spinels from upper mantle peridotites and megacryst assemblages; Geochim. Cosmochim. Acta. 456 899-913

Christie D M, Carmichael Jan S E and Langmuir Ch H 1986 Oxfidation states of mid-ocean ridge basalt glasses; Earth and Planet. Sci. Lett. 79 397-411 
Eggler D H 1983 Upper mantle oxidation state: Evidence from olivine orthopyroxene-ilmenite assemblages; Geophys. Res. Lett. 10 365-368

Green D H, Faloon T J, Brey G P and Nickel K G 1986 Peridotite melting to 6 GPa and genesis of primary mantle-derived magmas. 4th IKC Extended Abstracts; Geol. Soc. Austr. 16 181-183

Haggerty S E 1986 Diamond genesis in multiply-constrained model; Nature (London) 3206057 34-38

Haggerty S F and Topkins L A 1985 Redox state of the Earth's upper mantle from kimberlitic ilmenites; Nature (London) 303 295-300

Kadik A A 1988 Effects of melting on the evolution of fluid and redox conditions in the upper mantle; Geochem. Int. 25 9 76-84

Kadik A A and Lukanin O A 1985 Path of mantle outgassing during melting; the role of the partial melting of the upper mantle rocks in the evolution of fluid composition and redox regime; Int. Geol. Rev. $275562-563$

Kadik A A and Lukanin O A 1986 Degassing of the outer shells of the planets under magma-ocean conditions; Geochem. Int. 2 147-156 (in Russian)

Kadik A A, Sobolev N V and Zharkova E V 1989 Redox conditions of formation of diamond-bearing peridotite xenoliths from Udachnaya kimberlite pipe, Yukutia; Geochem. 8 1120-1134 (in Russian)

Kadik A A and Zharkova E V 1990 Redox evolution of basaltic magmas; Geochem. (in press)

Kadik A A, Zharkova E V, Kovalenko V J (1988) Redox conditions in the upper mantle: experimental determination of oxygen fugacity for minerals of peridotite xenoliths of Shavaryn-Tsaram volcano; Geochem. 6 783-793 (in Russian)

Lukanin O A and Kadik A A 1987 The melting of ultrabasic matter of the upper mantle in presence of graphite phase and at different redox regime; Volcanol. and Seismol. 2 3-13 (in Russian)

Mattioli G S, Baker M B and Rutter M J 1990 Upper mantle oxygen fugacity and its relationship to metasomatism; J. Geol. (in press)

McMahon B, Haggerty S E 1984 The Benfontein kimberlite sills: magmatic reaction and high intrusion temperatures; Am. J. Sci. 284 893-941

O'Neill H St C and Wall V J 1987 The olivine-orthopyroxene-spinel oxygen geobarometer, the nickel precipitation curve, and the oxygen fugacity of the Earth's upper mantle; J. Petrol. $2861169-1191$

Pokhilenko N P, Sobolev N V 1986 Xenoliths of diamondoferrous peridotites from Udachnaya kimberlite pipe, Yakutia. 4th IKC, Extended Abstracts; Geol. Soc. Aust. 16 309-310

Press S, Witt G and Seck H A 1986 Spinel peridotite xenolith from the Tariat depression, Mongolia. Major element chemistry and mineralogy of a primitive mantle xenolith suite; Geochim. Cosmochim. Acta. 50 2587-2599

Sato M 1972 Intrinsic oxygen fugacity of iron-bearing oxide and silicate minerals under low total pressure; Geol. Soc. Am. Mem. 135 289-307

Sato M 1976 Oxygen fugacity and other thermochemical parameters of Apollo 17 high-Ti basalts and their implications on the reduction mechanism; Proc. Seventh Lunar Sci. Conf. 1323-1344

Sato M, Hicking Nelson L and McLane John E 1973 Oxygen fugacity values of Appolo 12, 14 and 15 lunar samples and reduced state of lunar magmas; Proc. Fourth Lunar Sci. Conf. 1 Geochim. Cosmochim. Acta Suppl. 4, 1061-1079

Sato M and Valenza M 1980 Oxygen fugacities of the layered series of the Skaergaard intrusion, East Greenland; Am. J. Sci. A280 134-158

Shilobreeva S N, Kadik A A 1990 Carbon and its volatile compounds in silicate melts and crystals: experimental data; Proceeding of the First Indo-Soviet Workshop of Experimental Mineralogy and Petrology, New Delhi, December 1987, 39-41

Shilobreeva S N, Kadik A A, Minayev N M 1987 Analysis of carbon in natural olivine crystals of deep origin; Reports of USSR Academy of Sciences 2972 457-461 (in Russian)

Shilobreeva S N, Kadik A A, Senin V G et al 1989 Experimental determination of solubility of carbon in forsterite crystals and basaltic melts at $25-50 \mathrm{~kb}$ and $1700-1800^{\circ} \mathrm{C}$.; Geochem. (in press) (in Russian)

Sobolev N V 1977 Deep-seated inclusions in kimberlites and problem of the composition of the upper mantle; Am. Geophys. Union-Washington 279

Sobolev N V, Pokhilenko N P, Carwell Da 1986 Sheared lherzolites from kimberlites of Yakutia, 4th IKC Extended Abstracts; Geol. Soc. Aust. 16 338-339

Ulmer G C, Grandstaff D E and Weise D 1987 The mantle redox state: an unfinished story; Geol. Soc. Am. Spec. Pap. 215 5-23

Ulmer G C, Rosenhauer M, Woermann E 1976 Applicability of electrochemical oxygen fugacity measurements to geothermometry; Am. Mineral. 61 653-660

Woermann E and Rosenhauer M 1985 Fluid phases and the redox state of the Earth's mantle. Extrapolations based on experimental, phase-theoretical and petrological data; Fortschr. Mineral. 632 263-349 